\title{
The factor structure of the childbirth self-efficacy inventory in a sample of Turkish pregnant women
}

\author{
Türk gebe kadınlarda doğum öz yeterliliği ölçeğinin faktör yapısı
}

\author{
Ruveyde Aydın ${ }^{1}$, (D) Fatmanur Sena Bostan², (D Kamile Kabukçuoğlu
}

${ }^{1}$ Asst. Prof., Karadeniz Teknik

University, Faculty of Health Sciences,Department of Nursing, Trabzon, Turkey.

${ }^{2}$ Lec., Kütahya University of Health Sciences, Faculty of Health Sciences, Departmnet of Nursing, Kütahya, Turkey.

${ }^{3}$ Prof., Akdeniz University, Faculty of Nursing, Department of Obstetrics and Gynecology Nursing, Antalya, Turkey.

Sorumlu Yazar: Kamile Kabukçuoğlu, Prof., Akdeniz University, Faculty of Nursing, Department of Obstetrics and Gynecology Nursing, Antalya, Turkey. E-mail:kkamile@akdeniz.edu.tr. Telefon: +90 5057970464 .

Atıf İçin: Ruveyde Aydın, Fatmanur Sena Bostan, Kamile Kabukçuoğlu, The Factor Structure of the Childbirth Self-Efficacy Inventory in a Sample of Turkish Pregnant Women, 2021;5(3):131-139.

\section{ABSTRACT}

Aim: Childbirth self-efficacy is very important for the type and management of birth. Women with high self-efficacy prefer vaginal delivery, manage labor pain more easily, need fewer analgesic interventions, and experience fewer complications at birth. This study aimed to examine the factor structure of the Childbirth Self-Efficacy Inventory Short-Version (CBSEI-32) in Turkish pregnant women. Material and Method: This study was conducted in a methodological design. The sample of the study consisted of the pregnant women admitted to the obstetrics and gynecology outpatient clinic of Karaman State Hospital. The data were collected using the descriptive information form for the pregnant and the CBSEI. Numbers, percentages, arithmetic mean, factor analysis, and Cronbach's alpha coefficient were used in the data analyses. Result: As a result of the exploratory factor analysis (EFA), items 6, 12, 13 and 16 in the OE subdimension were excluded because their factor load values were below 0.32 . And the two-factor structure consisting of 28 items was obtained as the outcome expectancy (OE) and the selfefficacy expectancy (EE). Confirmatory factor analysis (CFA) was performed to obtain additional evidence of construct validity in line with the scores of the scale. It was determined that the fit indices calculated as a result of CFA without any modification were $p=0.00, \square 2 / S D ; 2.43, G F I=0.90$, $A G F I=0.90, C F I=0.90$, and RMSEA=0.06. The total Cronbach's alpha reliability coefficient was 0.82 . Conclusion: The study demonstrated that the Turkish version of the "Childbirth Self-Efficacy Inventory" is a valid and reliable tool to measure the childbirth self-efficacy of women during pregnancy.

Keywords: childbirth; self-efficacy; pregnancy; childbirth self-efficacy; nursing care

\section{Ōz}

Amaç: Doğumda öz-yeterlik, doğumun türü ve yönetimi için önemlidir. Yüksek öz yeterliliğe sahip kadınlar vajinal doğumu tercih etmekte, doğum ağrısını daha kolay yönetmekte, daha az analjezik müdahaleye ihtiyaç duymakta ve doğumda daha az komplikasyon yaşamaktadır. Bu çalışma, Türk gebelerde Doğum Öz Yeterlik Envanteri Kısa Versiyonunun (CBSEI-32) faktör yapısını incelemeyi amaçlamaktadır. Gereç ve Yöntem: Buçalışmametodolojikbirtasarımdayapılmıştır. ÇalışmanınörnekleminiKaraman Devlet Hastanesi Kadın Hastalıkları ve Doğum Polikliniğine başvuran gebeler oluşturmuştur. Veri toplamaaracıolarak, anneleritanıtıcıbilgiformuveDoğumÖz-yeterlilikÖlçeğikullanılmıştı. Verilerin analizinde sayı, yüzde, aritmetik ortalama, faktör analizi ve Cronbach alfa katsayısı kullanılmıştır. Bulgular: Açımlayıcı faktör analizi (AFA) sonucunda sonuç beklentisi (SBAS) alt boyutunda yer alan $6,12,13$ ve 16 . maddeler faktöryük değerleri 0.32 'nin altında olduğu için çıkarılmıştır. 28 maddeden oluşan iki faktörlü yapı ise sonuç beklentisi (SBAS) ve öz-yeterlik beklentisi (EBAS) olarak elde edilmiştir. Ölçekten elde edilen puanlar doğrultusunda yapı geçerliliğine ilişkin ek kanıt elde etmek amacıyladoğrulayıcıfaktöranalizi(DFA) uygulanmıştır. HerhangibirmodifikasyonunyapılmadığıDFA sonucunda hesaplanan uyum indekslerinin $p=0.00, \square 2 / \mathrm{sd}=2.43, \mathrm{GFI}=0.90, \mathrm{AGFI}=0.90, \mathrm{CFI}=0.90$ ve RMSEA $=0.06$ olduğu belirlenmiştir. Ölçeğin genel Cronbach Alfa katsayısı 0.82 olarak bulunmuştur. Sonuç: Bu çalışma, “Doğum Öz-yeterlik Ölçeği”nin Türkçe versiyonunun kadınların gebelik sırasında doğum öz-yeterliğini ölçmek için geçerli ve güvenilir bir araç olduğunu göstermiştir.

Anahtar Kelimeler: doğum; öz-yeterlik; gebelik; doğumda öz-yeterlik; hemşirelik bakımı 


\section{INTRODUCTION}

Giving birth is a turning point for women in which significant changes occur. Birth-related experiences, an important event in a woman's life and transition to motherhood, are subjective, psychological and physiological processes influenced by social and environmental factors (1). Birth experiences are individual and interpretations of this idiom vary from woman to woman (2). For some women, birth experiences mean an exciting and beautiful event, while for others, it means a very difficult, stressful, tiring, and unpredictable experience (3). And negative birth experience birth can become a traumatic situation for women (4). It can negatively affect the woman's next birth type, maternal function, and psychological health (5). Therefore, it is of great importantance to perceive birth positively (6).

One way to examine a pregnant woman's perception of birth is to determine her self-efficacy $(7,8)$. Knowing the level of self-efficacy at birth is an indirect way to predict a woman's perception of birth, how much effort she will have at birth, and how long she can maintain behaviors that help keep her in control of the birth process (9). Fear of birth and pain are the main sources of stress that can affect a woman's perception of control (10). Literature informs that women with high birth self-efficacy perceive less pain, their fear of birth is lower $(11,12)$, their beliefs in coping with physical problems and their psychological well-being are higher, and they experience their birth positively $(8,9)$. Women with high self-efficacy at birth can control their stress at birth and use their coping methods more actively (13). Relevant studies suggested that the active participation of pregnant women in the decision-making process related to labor increased the satisfaction of birth $(14,15)$.

The positive perception of birth enhances the satisfaction of birth, the attachment of the mother and the baby, the adaptation to motherhood and maternal function, and strengthens the communication within the family $(16,17)$. Therefore, the high childbirth self-efficacy level is important not only for the birth process but also for birth type preference, the effective establishment of domestic processes in the postpartum period, adaptation of the woman to the role of motherhood, personal strengthening of the woman and the national economy (17). World Health Organization (2015) recommend respectful maternal care, which is designed to protect the dignity, privacy, and confidentiality of all women, with a human rights-based approach for a positive birth experience for women, which prevents them from being harmed and mistreated, and enables them to make conscious choices and receive continuous support during delivery (18). Enhancing childbirth self-efficacy is the primary responsibility of midwives and nurses providing prenatal care to pregnant women (19). Midwives and nurses can take an active part in childbirth preparation training and communicate with women in the prenatal period and provide effective care that women need by identifying issues $(20,21)$.

\section{THEORY}

Self-efficacy was first defined by Albert Bandura in 1977 as an individual's belief that he/she will complete an existing situation or achieve a task in the context of "Social Cognitive Theory" (22). Self-efficacy is an important feature that determines how an individual feel, thinks, and behaves in a situation (22). People's self-efficacy affects their beliefs about how well they will learn what they choose to learn (23). Bandura (1977) based the self-efficacy theory on four main factors: situations which one can directly experience, experiences learned indirectly, verbal persuasion, and psychological states. According to the theory, individuals can learn the experiences of others in addition to their own experiences by observing or even by reading the experiences of a character in the book through symbolic modeling $(22,23)$.

Lowe (1993) was influenced by Bandura's self-efficacy theory and investigated the concept of birth self-efficacy extensively and found self-confidence as the most critical variable in the management of birth pain (24). Lowe (1993) provided a conceptual framework for self-efficacy at birth with four mechanisms: previous birth experience, birth experiences heard from others, verbal persuasion, and psychological states (panic, anxiety, etc.). In 1993, Lowe developed the 62-item "CBSEl" to measure maternal self-efficacy in coping with labor pain (24). In this inventory, pregnant women were examined in four subscales as outcome expectancies in the active phase of birth, self-efficacy in the active phase of birth, outcome expectancies in the second stage of birth, and self-efficacy in the second stage of birth. Ip, Chung \& Tang (25) removed repetitive items from the scale and reduced it to two sub-scales as outcome expectancy (OE) and self-efficacy expectancy (EE) and presented the 32-item short form of the CBSEI-32 to the literature.

The study aimed to examine the factor structure of the Childbirth Self-Efficacy Inventory Short-Version (CBSEI) in Turkish pregnant women.

Hypothesis 1 (H1) The Turkish version of the CBSEl-32 is two-dimensional

Hypthesis $2(\mathrm{H} 2)$ The Turkish version of the CBSEI-32is reliable and valid among Turkish pregnant women.

\section{MATERIAL AND METHODS}

\section{Design}

This study was carried out a cross-sectional design to examine the factor structure of the "Childbirth Self-Efficacy Inventory Short-Version" in Turkish pregnant women which was developed by Ip, Chung \& Tang (25). 


\section{Participant and setting}

The population of the study consisted of pregnant women admitted to the Obstetrics and Gynecology outpatient clinic at Karaman State Hospital. The sample included pregnant women who met the inclusion criteria of the study. The inclusion criteria were being voluntary to participate in the study, being pregnant over the age of 18, and under 45 years, having a single pregnancy, and being at $26^{\text {th }}-40^{\text {th }}$ week of gestation. Exclusion criteria were having a chronic illness, high-risk pregnancy, and a psychiatric disorder and being unable to speak or read Turkish fluently.

A simple random sampling method was used to determine the sample size. The sample should be at least 5 and ideally 10 times more than the number of items of the scale to make factor analysis in the scale validity and reliability studies (26). Since there are 32 items in the Childbirth Self-Efficacy Inventory, the sample should be at least 320 people. However, against the possibility of extreme and missing values, a total of 350 pregnant women were reached.

\section{Ethical considerations}

To examine the psychometric properties of the Childbirth Self-Efficacy Inventory, written permission was obtained from its owner, Ip Wan-Yim, by e-mail. Before starting the study, approval was obtained from Akdeniz University Clinical Research Ethics Committee (2012-KAEK-20) and permission from Karaman Provincial Health Directorate.

\section{Data collection}

The data were collected by using face-to-face interviews between 2019 and 2020 from pregnant women admitted to Karaman State Hospital Obstetrics and Gynecology outpatient clinic for examination. It took 5-10 minutes to interview with each participant. To collect the data, a descriptive information form and the Childbirth Self-Efficacy Inventory were used.

The descriptive information form for pregnant women: Prepared by the researchers based on the literature, the form includes 12 questions regarding the socio-demographic characteristics (age, education, working status) and obstetric characteristics (parity, gestational week, curettage status, spouse support, etc.) of the participants.

The Childbirth Self-Efficacy Inventory: "The Childbirth Self-Efficacy Inventory Short-Version" was developed by Ip, Chung \& Tang (2007) to measure self-efficacy levels at birth. It consists of two sub-scales: the outcome expectancy (OE) and the self-efficacy expectancy (EE) (25). Each sub-scale includes 16 questions. The lowest and highest total scores that can be obtained from the Childbirth Self-Efficacy Inventory is 32 and 320 respectively. Likert-type responses were scored as 1-10. In the outcome expectancy sub-scale, 1 means "not useful at all" and 10 means "very useful". In the first 13 questions in the selfexpectancy sub-scale, 1 means "I am absolutely sure" and 10 means "I am not sure at all". In the questions 14-16, 1 means "I am not sure at all", and 10 means "I am absolutely sure". The questions from 1 to 13 on the self-efficacy expectancy sub-scale are reversed and scored. The overall Cronbach's alpha value was 0.92 and 0.82 in the self-efficacy sub-scale respectively. The validity and reliability study of the scale was performed by Ersoy \& Kabukcuoğlu (Kukulu) (27) in the master thesis. However, in the thesis, the factor structure was not confirmed by confirmatory factor analysis, and it has not been published as a scientific publication. For this reason, the factor structure of the scale was re-examined with permission from Ip.

\section{Data analysis}

SPSS (Statistical Package for Social Sciences, version 23.0 SPSS Inc., Chicago, IL, USA) were used for statistical analyses. While the percentages and frequencies were used in the analysis of socio-demographic data, Exploratory and Confirmatory factor analyses were used for the construct validity in the validity and reliability of the scale. Cronbach's alpha coefficient was calculated for internal consistency.

\section{Cross-cultural adaptation process}

The language and content validity of the scale was performed by Ersoy (27) in the master thesis. For the content validity, the evaluations of the five experts on the applicability and intelligibility of the scale items in the assessment of the Childbirth Self-Efficacy Scale were found to be statistically compatible with each other (Kendall's Wa=0.289, Sd=31, $p=0.052$ ). In this study, the Turkish version of the scale was used with permission.

\section{RESULTS}

More than half $(55.1 \%)$ of the pregnant women were $26-35$ years old, the majority were married (99.4\%), unemployed $(76.6 \%)$ and housewives $(74.0 \%)$. Half of them were at $26^{\text {th }}-30^{\text {th }}$ week of gestation, the majority had spousal support $(84.9 \%)$, they had previous pregnancy experience $(69.7 \%)$, they did not receive childbirth preparation training (67.1\%), and more than half were satisfied with their previous birth experience (58.5\%) (Table 1). 
Table 1. Descriptive characteristic of pregnant women

\begin{tabular}{|c|c|c|}
\hline Descriptive characteristics & $\mathbf{n}$ & $\%$ \\
\hline $\begin{array}{l}\text { Age } \\
18-25 \text { years old } \\
26-35 \text { years old } \\
36-45 \text { years old } \\
\text { Mean } \pm s s=27.50 \pm 5.34\end{array}$ & $\begin{array}{l}118 \\
193 \\
39\end{array}$ & $\begin{array}{l}33.7 \\
55.1 \\
11.1\end{array}$ \\
\hline $\begin{array}{l}\text { Marital status } \\
\text { Married } \\
\text { Single } \\
\end{array}$ & $\begin{array}{l}348 \\
2 \\
\end{array}$ & $\begin{array}{l}99.4 \\
0.6\end{array}$ \\
\hline $\begin{array}{l}\text { Educational status } \\
\text { Primary school } \\
\text { High school } \\
\text { Associate Degree } \\
\text { Bachelor's and Post graduate Degree }\end{array}$ & $\begin{array}{l}149 \\
106 \\
50 \\
45\end{array}$ & $\begin{array}{l}42.6 \\
30.3 \\
14.3 \\
12.8\end{array}$ \\
\hline $\begin{array}{l}\text { Employment status } \\
\text { Unemployed } \\
\text { Employed }\end{array}$ & $\begin{array}{l}268 \\
82\end{array}$ & $\begin{array}{l}76.6 \\
23.4\end{array}$ \\
\hline $\begin{array}{l}\text { Occupation } \\
\text { Housewife } \\
\text { Worker } \\
\text { Civil Servant } \\
\text { Others } \\
\end{array}$ & $\begin{array}{l}259 \\
36 \\
18 \\
36 \\
\end{array}$ & $\begin{array}{l}74.0 \\
10.6 \\
5.2 \\
10.3 \\
\end{array}$ \\
\hline $\begin{array}{l}\text { Social security } \\
\text { Yes } \\
\text { No }\end{array}$ & $\begin{array}{l}304 \\
46\end{array}$ & $\begin{array}{l}86.9 \\
13.1\end{array}$ \\
\hline $\begin{array}{l}\text { Gestational week } \\
\text { 26-30. weeks } \\
\text { 31-35. weeks } \\
\text { 36-40. weeks }\end{array}$ & $\begin{array}{l}175 \\
94 \\
81\end{array}$ & $\begin{array}{l}50 \\
26.9 \\
23.1\end{array}$ \\
\hline $\begin{array}{l}\text { Spousal support } \\
\text { Yes } \\
\text { No } \\
\text { Partial } \\
\end{array}$ & $\begin{array}{l}297 \\
14 \\
39 \\
\end{array}$ & $\begin{array}{l}84.9 \\
4.0 \\
11.1 \\
\end{array}$ \\
\hline $\begin{array}{l}\text { Previous pregnancy } \\
\text { Yes } \\
\text { No } \\
\end{array}$ & $\begin{array}{l}244 \\
106 \\
\end{array}$ & $\begin{array}{l}69.7 \\
30.3 \\
\end{array}$ \\
\hline $\begin{array}{l}\text { Miscarriage experience } \\
\text { Yes } \\
\text { No }\end{array}$ & $\begin{array}{l}87 \\
263 \\
\end{array}$ & $\begin{array}{l}24.9 \\
75.1 \\
\end{array}$ \\
\hline $\begin{array}{l}\text { Status of childbirth preparation training } \\
\text { Yes } \\
\text { No }\end{array}$ & $\begin{array}{l}115 \\
235\end{array}$ & $\begin{array}{l}32.9 \\
67.1\end{array}$ \\
\hline $\begin{array}{l}\text { Previous birth satisfaction } \\
\text { Very satisfied } \\
\text { Satisfied } \\
\text { A bit satisfied } \\
\text { Not satisfied }\end{array}$ & $\begin{array}{l}47 \\
133 \\
27 \\
20\end{array}$ & $\begin{array}{l}20.8 \\
58.5 \\
11.9 \\
8.8\end{array}$ \\
\hline
\end{tabular}

\section{Exploratory Factor Analysis}

First of all, exploratory factor analysis (EFA) was performed to obtain evidence of construct validity in line with the scores obtained from the Childbirth Self-Efficacy Inventory. Kaiser-Meyer-Olkin (KMO) test was applied before the EFA to test the suitability of the sample size for factorization. As a result of the analysis, it was found that KMO values were 0.87 for the basal data set, and chi-square value of Barlett sphericity test was highly significant $(\chi 2(351)=3574,564) p=0.000$. There were no multicollinearity and loss value problems among the items. The data were found to be suitable for factor analysis.

Firstly, in the exploratory factor analysis performed for the Childbirth Self-Efficacy Inventory, when factor load value was taken 0.40 , factorization could not be achieved. So, the level of acceptance for factor load values was determined as 0.32 in the exploratory factor analysis revealing the factor pattern of CBSE. The most appropriate factor structure was found to 
be a factor structure similar to the original scale, which is a two- factor structure. In the analysis of the two-factor structure, when the items were evaluated in terms of whether the factor load values met the acceptance level or not and whether they were loaded under more than one factor, it was determined that factor load values of 6,12, 13 and 16 items in the OE sub-scale were found to be below 0.32 . Factor analysis was performed again with the varimax rotation method considering the remaining 28 items. Factor pattern obtained as a result of the exclusion of these items, factor load values, and common factor variances of the items is given in Table 2.

Table 2 shows that factor load values at the subscales level range between 0.43 and 0.69 for the outcome expectancy subscale and between 0.37 and 0.79 for the self-efficacy expectancy subscale. The contribution of these two factors to the total explained variance was found to be $50.3 \%$.

Table 2. Factor Pattern of Childbirth Self-Efficacy Scale (Exploratory Factor Analysis)

\begin{tabular}{|c|c|c|c|}
\hline Items & Outcome Expectancy & Self-efficacy Expectancy & Common Factor Variance \\
\hline OE10 & 0.69 & & 0.80 \\
\hline OE7 & 0.65 & & 0.75 \\
\hline OE4 & 0.65 & & 0.69 \\
\hline OE14 & 0.61 & & 0.76 \\
\hline OE5 & 0.62 & & 0.70 \\
\hline OE8 & 0.58 & & 0.61 \\
\hline OE2 & 0.58 & & 0.56 \\
\hline OE1 & 0.57 & & 0.55 \\
\hline OE3 & 0.56 & & 0.54 \\
\hline OE11 & 0.50 & & 0.62 \\
\hline OE9 & 0.51 & & 0.67 \\
\hline OE15 & 0.43 & & 0.56 \\
\hline EE4 & & 0.79 & 0.80 \\
\hline EE10 & & 0.77 & 0.78 \\
\hline EE3 & & 0.76 & 0.61 \\
\hline EE9 & & 0.73 & 0.69 \\
\hline EE8 & & 0.72 & 0.59 \\
\hline EE7 & & 0.72 & 0.67 \\
\hline EE5 & & 0.69 & 0.72 \\
\hline EE12 & & 0.66 & 0.60 \\
\hline EE1 & & 0.66 & 0.54 \\
\hline EE2 & & 0.65 & 0.55 \\
\hline EE11 & & 0.60 & 0.59 \\
\hline EE13 & & 0.56 & 0.70 \\
\hline EE6 & & 0.41 & 0.64 \\
\hline EE14 & & 0.39 & 0.53 \\
\hline EE15 & & 0.38 & 0.79 \\
\hline EE16 & & 0.37 & 0.75 \\
\hline
\end{tabular}

\section{Confirmatory factor analysis (CFA)}

In the second stage of the study, CFA was used to test the compliance of the factors determined by EFA with the factor structures determined by the hypothesis. Measurement models aim to reveal how a group of observable variables (as a measurement tool) explains the latent variables called factors. By establishing the first level DFA model, latent factors in CBSEI's structure, and the interdependent effects between these factors were tested in the AMOS program. The first dimension of CBSEl consisting of two dimensions is the outcome expectancy (OE) and the second dimension is the selfefficacy expectancy (EE). OE and EE ellipse, which are not observed variables, are shown in the road diagram in Figure 1. These two factors are interrelated and are indicated by a two-way arrow. 28 observed variables representing the factors are shown with 28 rectangles. Each observed variable is loaded with a single factor. The observed variables and measurement errors are not correlated. The factor structure of the Childbirth Self-Efficacy Inventory was tested with confirmatory factor analysis. The diagram for confirmatory factor analysis is given below (Figure 1). 


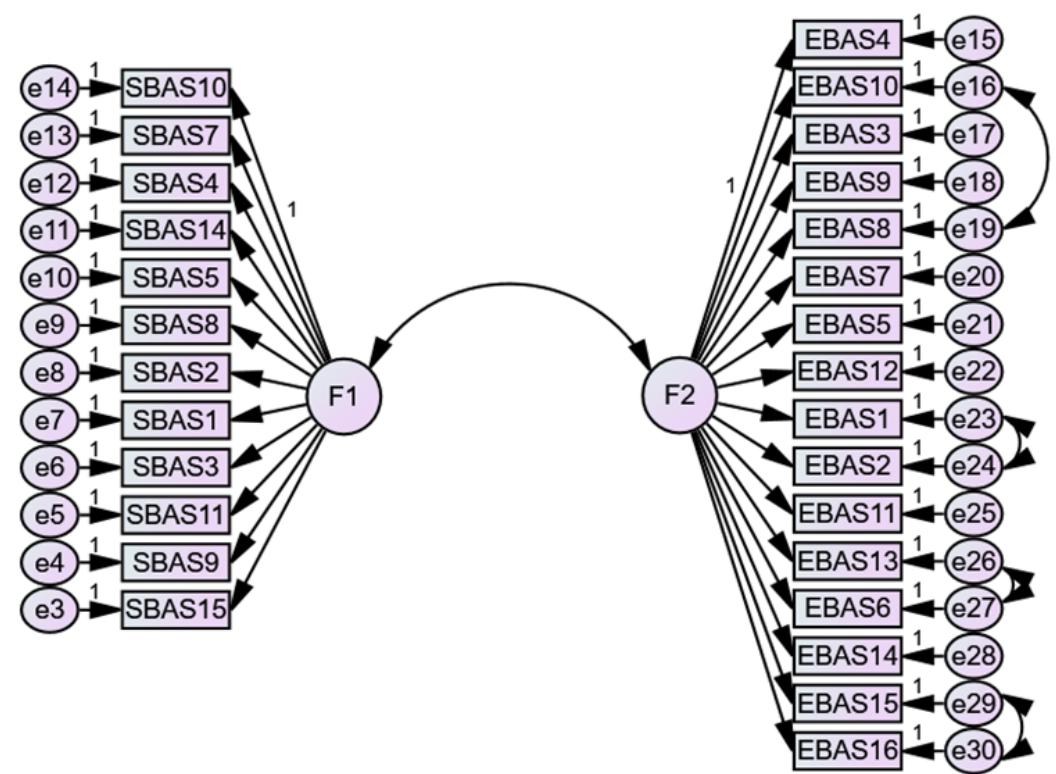

Figure 1. Diagram of Confirmatory Factor Analysis of Childbirth Self-Efficacy Inventory NOTE: $S B A S=O E$ and EBAS: $E E$

It was determined that the fit indices calculated as a result of CFA without any modification were $p=0.00, \chi^{2} /$ $\mathrm{sd}=2.43, \mathrm{GFI}=0.90, \mathrm{AGFI}=0.90, \mathrm{CFI}=0.90$ and RMSEA=0.06 (Table 3).

Table 3. Confirmatory factor analysis index values of Childbirth Self-Efficacy Inventory

\begin{tabular}{|l|c|c|c|}
\hline Index & Normal Value* & Acceptable Value ** & Childbirth Self-Efficacy Inventory \\
\hline$\chi 2 / s d$ & $<2$ & $<5$ & $2.43(838.5 / 345)$ \\
\hline GFI & $>0.95$ & $>0.90$ & 0.90 \\
\hline AGFI & $>0.95$ & $>0.90$ & 0.90 \\
\hline CFI & $>0.95$ & $>0.90$ & 0.90 \\
\hline RMSEA & $<0.05$ & $<0.08$ & 0.06 \\
\hline
\end{tabular}

Cronbach's alpha coefficient was used for internal consistency analysis to determine the reliability of the Childbirth Self-Efficacy Inventory. As a result of the analysis, the Cronbach's alpha coefficient of the outcome expectancy (OE) subscale was 0.82 , the Cronbach's alpha coefficient of the self-efficacy expectancy (EE) subscale was 0.90 , and the overall Cronbach's alpha coefficient was 0.82 (Table 4).

Table 4. Sub-scales of the Childbirth Self-Efficacy Inventory and Overall Cronbach's Alpha

\begin{tabular}{|l|c|}
\hline Sub-Scales & Cronbach's Alfa \\
\hline Outcome expectancy & 0.82 \\
\hline Self-Efficacy expectancy & 0.90 \\
\hline Overall & 0.82 \\
\hline
\end{tabular}

\section{DISCUSSION}

Cesarean birth rates are increasing day by day due to many reasons such as negative birth experiences, lack of information about vaginal birth, the impact of media and environment, fear of birth, and attitude of health professionals (28). To increase vaginal birth rates, midwives and nurses should inform women through childbirth preparation training, change their negative perceptions of birth and increase their self-efficacy at birth (29). Therefore, the present study aimed to evaluate the psychometric properties of the Turkish version of the Childbirth Self-Efficacy Inventory (CBSEI-C32) among pregnant women in Turkey. The present hypotheses addressed evidence related to the dimensionality, reliability and construct validity of the CBSEI-C32 in a Turkish pregnant women.

The first hypothesis (H1) concerned how well the original two-factorial measurement model of the CBSEI-C32 fit with the observed data. The varimax-rotated EFA demonstrated two factors with eigenvalue 1.0, and explaining $63 \%$ of the variation. In this study and in Iran (30), China(10) and Tanzania(31) where the scale was adapted, outcome expectation (OE) and self-efficacy expectation (EE) sub-dimensions were obtained, which were the same as the original scale. 
The secand hypothesis $(\mathrm{H} 2)$ tested the reliability and construct validity of the CBSEI-C32 in this population. In this study, as a result of exploratory factor analysis, two sub-scales (expectancy and self-efficacy expectancy) were reached outcome as in the original scale by Ip, Chung \& Tang (25) (Table 2). The factor load value indicates the relationship of the items with the factors and is taken into account in excluding items from the scale. There is a widespread opinion that the minimum size of the factor load value of an item is 0.30 or 0.40 , which is often recommended in practice (32). In this study, to reveal the factor pattern of CBSEI-C32, in the exploratory factor analysis, the acceptance level for factor load values was determined as 0.32 . The factor load values of items $6,12,13$, and 16 in the OE sub scale were below 0.32 , so they were excluded from the analysis. In dealing with labor pain in a cultural perspective, expressions with OE6 item (Concentrate on an object in the room to distract myself), OE12 item (Tell myself that I can do it) and OE13 item (Think about others in my family) are generally not applied in Turkey. OE16 item which is about the encouragement words of the person who helps birth revealed a bad fit displaying low reliability (low factor loadings). It is thought that this may be due to the lack of empathic communication skills of midwives and physicians who help birth. It is also the first pregnancy of most of the pregnant women in this study, and women may have been adversely affected by the insufficient empathic communication skills of midwives and doctors at birth in examples of Turkish movies and bad birth stories of those around (33). After these items were excluded from the scale, the factor load value of the OE sub-dimension was between 0.43 and 0.69 , while the factor load values of the EE sub-dimension varied between 0.37 and 0.79 (Table 2). In the Iranian version of the scale (30) the factor load values of the items were 0.41 to 0.71 , and as in the Chinese version (10) the factor load values of the items changed 0.43 to 0.85 and in the Tanzanian version (31) the factor load values of the items were above 0.32 , no item was excluded from the analysis.

Cronbach's alpha assess the internal consistency of a scale. For both reliabilty coefficients a reliability-level of $\geq 0.70$ is interpreted as good (27). In this study, it was found that the general Cronbach's alpha of the scale was 0.82, the OE subscale was 0.82 , and the EE sub-scale was 0.90 which means that it is reliable. The total Cronbach's alpha values of the scale were higher than 0.80 in other studies to which the scale was adapted $(10,30,31)$.

Construct validity deals with the accuracy of measurement, reflecting the extent to which a set of measured indicators actually reflects the theoretical latent construct the items are designed to measure (34). A commonly used method to investigate construct validity is confirmatory factor analysis (CFA) (35). In this study, the most commonly used goodness of fit indices in the literature was used. When the CFA fit index of CBSEI-C32 was examined, $\chi 2$ degrees of freedom was found to be 2.45 ( $\leq 5$ ), other fit indices were acceptable.

In CFA, more than one fit index is obtained, and whether the scale validates the model is determined by evaluating not a single fit index but all indexes together (32). When the fit indexes were examined in general, the exploratory factor analysis structure of CBSEI-C32 was found to be well confirmed in the target culture. When we looked at the CFA results of the original scale, we found that $\chi 2$ degrees of freedom was $2.86(\leq 5)$, CFI was 0.96 ( $\geq 0.95=$ perfect fit), NNFI was 0.96 ( $\geq 0.95$ = perfect fit), IFI was 0.96 ( $\geq 0.95$ = perfect fit), and RMSEA was 0.08 ( $\leq 0.08=$ acceptable fit) as in this study Ip, Chung \& Tang (2007)(25). In studies conducted in the south of China (10) and Iranian (30) it was found that overall CFA fit indexes showed perfect fit.

\section{CONCLUSION}

The Turkish version of the CBSEI-C32 has 28 items and a two-factor dimension and shows good psychometric properties. Also, it was found to be short and feasible enough to be used as a clinical instrument for measuring childbirth self-efficacy in Turkish pregnant women. In addition, CBSEI-C32 is of great importance as it is a standard measurement tool that measures the self-efficacy of women during pregnancy according to international standards for high quality. This will contribute to the development of international methodology and literature.

Perinatal health professionals have a great role in increasing the childbirth self-efficacy of women. Health professionals should support the participation of all women of reproductive age in perinatal care services and should ensure that women learn about labor and delivery pain management methods by attending childbirth preparation classes during pregnancy. Health professionals should determine the childbirth self-efficacy level of women using the childbirth self-efficacy inventory after the training to increase the birth self-efficacy of women in the perinatal period. When necessary, additional training should be planned for women to increase their childbirth self-efficacy.

\section{ACKNOWLEDGMENTS}

The authors wish to especially thank all pregnant women who volunteered to participate in this study.

Financial Supoort: The author(s) received no financial support for the research.

Ethical Declaration:To examine the psychometric properties of the Childbirth Self-Efficacy Inventory, written permission was obtained from its owner, Ip Wan-Yim, by e-mail. Before starting the study, approval was obtained from Akdeniz University Clinical Research Ethics Committee (2012-KAEK-20) and permission from Karaman Provincial Health Directorate.

Conflict of Interest: The authors declare that they have no conflict of interests regarding content of this article. 


\section{REFERENCES}

1. Aktaş S, Aydın R. The analysis of negative birth experiences of mothers: a qualitative study. Journal of Reproductive Infant Psychology. 2019;37(2):176-192. doi:10.1080/02646838.2018.1540863

2. Yıldız H. Pozitif Doğum Deneyimi İçin İntrapartum Bakım Modeli: Dünya Sağıık Örgütü Önerileri. Kocaeli Üniversitesi Sağlık Bilimleri Dergisi, 2019; 5(2), 98-105.

3. Namujju J, Muhindo R, Mselle LT, Waiswa P, Nankumbi J, Muwanguzi P. Childbirth experiences and their derived meaning: a qualitative study among postnatal mothers in Mbale regional referral hospital, Uganda Reproductive Health. 2018;15(183):111. doi:10.1186/s12978-018-0628-y.

4. Ayers S. Birth trauma and post-traumatic stress disorder: the importance of risk and resilience. Journal of Reproductive Infant Psycholgy. 2017; 35(5): 427-432. doi.org/10.1080/02646838.2017.1386874

5. Aydın R, Barkin JL, Kukulu K. Attempts to strengthen maternal functioning in the postpartum period: a literature review. Journal of Human Science. 2016;13(3):5751-5759. doi: 10.14687/jhs.v13i3.4170.

6. Crawley R, Wilkie S, Gamble J, Creedy DK, Fenwick J, Cockburn N, Ayers S.. Characteristics of memories for traumatic and nontraumatic birth. Applied Cognitive Psychology 2018; 32(5): 584-591. doi.org/10.1002/acp.3438

7. Ip WY, Chung TK, Tang CS. The Chinese Childbirth Self-Efficacy Inventory: the development of a short form. Journal of Clinical. Nursing. 2008; 17(3):333-340. doi.org/10.1111/j.1365-2702.2006.01919.x

8. Ip WY, Tang CS, Goggins WB. An educational intervention to improve women's ability to cope with childbirth. Journal of Clinical. Nursing. 2009; 18(15): 2125-2135. doi.org/10.1111/j.1365-2702.2008.02720.x

9. Preis $\mathrm{H}$, Eisner $\mathrm{M}$, Chen R, Benyamini Y. First-time mothers' birth beliefs, preferences, and actual birth: A longitudinal observational study. Women and Birth 2019; 32(1): 110-117. doi:10.1016/j.wombi.2018.04.019

10. Gao LL, Ip WY, Sun K. Validation of the short form of the chinese childbirth self-efficacy inventory in Mainland China. Research in Nursing \& Health., 2010;34(1):49-59. doi:10.1002/nur.20400

11. Byrne J, Hauck Y, Fisher C, Bayes S, Schutze R. Effectiveness of a mindfulness-based childbirth education pilot study on maternal self-efficacy and fear of childbirth. Journal of Midwifery Womens Health 2014; 59(2): 192-197. doi.org/10.1111/ jmwh.1207

12. Serçekuş $P$, Başkale $H$. Effects of antenatal education on fear of childbirth, maternal self-efficacy and parental attachment. Midwifery. 2016;(34):166-172. doi:10.1016/j.midw.2015.11.016

13. Campbell V, Nolan M. "It definitely made a difference": a grounded theory study of yoga for pregnancy and women's self-efficacy for labour. Midwifery 2018; 1(68): 74-83. doi: 10.1016/j.midw.2018.10.005

14. Aktaş S, Aydın R. The analysis of negative birth experiences of mothers: a qualitative study. Journal of Reproductive Infant Psychogyl. 2019;37(2): 176-192. doi.org/10.1080/02646838.2018.1540863

15. Nilsson L, Thorsell T, Hertfelt Wahn E, Ekström A. Factors influencing positive birth experiences of first-time mothers. Nursing Research Practice, 2013. https://doi.org/10.1155/2013/349124

16. Aydın R, Kukulu K. Adaptation of the Barkin scale of maternal functioning and examination of the psychometric properties. Health Care for Women International 2018;39(1): 50-64. doi.org/10.1080/07399332.2017.1385616

17. Reisz S, Jacobvitz D, George C. Birth and motherhood: childbirth experience and mothers' perceptions of themselves and their babies. Infant Mental Health Journal 2015; 36(2): 167-178. doi:10.1002/imhj.21500

18. WHO. Pregnancy, childbirth, postpartum and newborn care: a guide for essential practice -3rd ed. World Health Organization. 2015, WHO Press, Geneva, Switzerland

19. Carlsson IM, Ziegert K, Nissen E. The relationship between childbirth self-efficacy and aspects of well-being, birth interventions and birth outcomes. Midwifery. 2015;31(10):1000-1007. doi:10.1016/j.midw.2015.05.005

20. Maimburg RD, Vaeth M, Dahlen H. Women's experience of childbirth - A five year follow-up of the randomised controlled trial "Ready for Child Trial”. Women Birth, 2016;29(5): 450-454. doi:10.1016/j.wombi.2016.02.003 
21. Toohill J, Creedy DK, Gamble J, Fenwick J. A cross-sectional study to determine utility of childbirth fear screening in maternity practice - An Australian perspective. Women Birth. 2015;28(4):310-316. doi:10.1016/j.wombi.2015.05.002

22. Bandura A. Self-efficacy: Toward a unifying theory of behavioral change. Behaviour Research and Therapy. 1977; 1(4): 139-161. doi:10.1016/0146-1993; 6402(78): 90002-4

23. Yancey, George B. Self-efficacy. Salem Press Encyclopedia of Health. 2019;3p

24. Lowe NK. Maternal confidence for labor: development of the Childbirth Self-Efficacy Inventory. Research in Nursing \& Health 1993;16(2): 141-149. doi:10.1002/nur.4770160209

25. Ip WY, Chung TK, Tang CS. The Chinese Childbirth Self-Efficacy Inventory: the development of a short form. Journal Clinical Nursing 2007;17(3): 333-340. doi:10.1111/j.1365-2702.2006.01919.x

26. Şencan H. Sosyal ve davranışsal ölçümlerde güvenirlik ve geçerlilik. Ankara Seçkin Yayıncılık, 2005

27. Ersoy, Y. Doğum eyleminde öz-yeterlilik ölçeği geçerlik ve güvenirlik çalışması (unpublished master thesis). Antalya; Akdeniz Üniversitesi, 2011

28. Kızılkaya-Beji N. Hemşire ve ebelere yönelik kadın sağlığı ve hastalıkları. İstanbul; Nobel Tıp Kitabevleri, 2017

29. Çiçek Ö, Okumuş H. Self-efficacy perception at birth: its importance and effective factors. International Refereed Journal of Gynaecological Diseases and Maternal Child Health. 2017; May / June / July / August Summer (10):35-46.

30. Khorsandi M, Asghari Jafarabadi M, Jahani F. Cultural Adaptation and Psychometric Testing of the Short Form of Iranian Childbirth Self Efficacy Inventory. Iranian Red Crescent Medical Journal; 15(11): e11741 doi: 10.5812/ircmj.11741.

31. Björk E, Thorildsson M. Childbirth Self-Efficacy Inventory in Tanzania -a pilot study. Diva. 2007 retriver from ; https:// www.diva-portal.org/smash/record.

32. Çokluk Ö, Şekercioğlu G, Büyüköztürk Ş. Sosyal bilimler için değişkenli istatistik uygulamaları. Ankara; PegemAkademi Yayıncılık, 2012

33. Aktaş S, Pasinlioğlu T, Çalik K. The Effect of Empathy Traning Given to Midwives on Mothers' Birth Perceptions and Their Satisfaction with Midwives. Life Science. 2016; 11(3), 1-10.

34. Tabachnick BG, Fidell LS. Using Multivariate Statistics (7th ed.). Harlow: Pearson Education Inc, 2019

35. Fournier-Vicente $S$, Larigauderie $P$, Gaonac'h D. More dissociations and interactions within central executive functioning: A comprehensive latent-variable analysis. Acta psycholgy, 2018; 129(1), 32-48. 